\title{
ANALISIS KEPRIBADIAN TOKOH KAI AMAK DALAM NOVEL GALUH HATI KARYA RANDU ALAMSYAH
}

\author{
Sumiharti ${ }^{1}$, Ronizar Ilham ${ }^{2}$ \\ Program Studi Pendidikan Bahasa dan Sastra Indonesia, \\ Fakultas Keguruan dan Ilmu Pendidikan, Universitas Batanghari, \\ Jambi \\ harti.sumi@yahoo.com \\ ronizarilham@gmail.com
}

\begin{abstract}
This research is aimed at describing the character of Kai Amak in the novel Galuh Hati by Randu Alamsyah. This research uses qualitative descriptive method. The primary data is in the form of sentences and expressions which represents id, ego, and super ego occured in the novel Galuh Hati by Randu Alamsyah. In collecting the data, the documentation technique is used. Based on the result of the analysis, it is found that there are 45 expressions which represents id, ego, and super ego. There is 16 expressions of id aspect which can be found in his lust towards eat and drink, sex, ignoring the pain or uncomfortable feeling. There is 20 expressions of ego aspect which can be seen from his logic, problem-solving, and decision-making. Moreover, there is 9 expressions of super ego aspect which can be seen from his feeling of shame, guilty, and regret. So, it can be concluded that the character of Kai Amak has the id, ego, and super ego personality.
\end{abstract}

Keywords: Character, Novel

\footnotetext{
${ }^{l}$ Mahasiswa Program Studi Pendidikan Bahasa dan Sastra Indonesia, Fakultas Keguruan dan Ilmu Pendidikan, Universitas Batanghari, Jambi

2 Mahasiswa Program Studi Pendidikan Bahasa dan Sastra Indonesia, Fakultas Keguruan dan Ilmu Pendidikan, Universitas Batanghari, Jambi
}

Analisis Kepribadian Tokoh Kai Amak dalam Novel Galuh Hati Karya Randu Alamsyah 


\section{PENDAHULUAN}

Karya sastra merupakan sebuah produk seni hasil kreativitas manusia. Karya sastra terbentuk dari imajinasi, intuisi, ide serta pemikiran penciptanya yang dibuat dengan sepenuh hati. Karya sastra sendiri memiliki beragam wujud dan variasi diantaranya prosa, puisi, dan drama. Ketiga jenis karya sastra tersebut memiliki keistimewaan tersendiri. Puisi lebih menekankan pada pemaknaan dan pemilihan diksi. Unggul dalam bidang penjiwaan serta visual merupakan kelebihan dari drama, Sedangkan prosa memiliki kelebihan dalam segi pengimajian maupun kompleksitas alur cerita. Prosa dapat dibedakan berdasarkan panjang pendeknya cerita, antara lain: cerpen, roman, novelet, novel dan sebagainya. Dari semua wujud prosa, cerpen dan novel sangat sering kita jumpai.

Novel merupakan salah satu bentuk dari prosa yang selalu mendapat tempat di hati para penikmatnya, tidak heran novel eksis dari waktu ke waktu. Itu dapat kita buktikan saat mengunjungi sebuah tokoh buku, orang-orang lebih antusias mencari novel-novel terbitan baru dibanding membeli buku tentang ilmu pengetahuan. Novel yang ditulis merupakan hasil fiksi (rekaan) atau pengalaman hidup pengarang, maupun kombinasi keduanya. Dalam menulis novel pengarang wajib menuangkan kreativitas, ide-ide serta daya cipta sastra yang estetis. Hal-hal tersebut akan membuat novel unik, menarik, dan tidak membosankan untuk dibaca. Novel yang berkualitas biasanya memiliki jalan cerita (alur) yang rumit sehingga sulit ditebak oleh pembaca. Cerita yang disajikan biasanya sangat dekat dan hampir sama dengan kehidupan kita sehari-hari. Maka dari itu, novel merupakan media atau sarana yang pas untuk menyampaikan pesan tertentu oleh pengarang. Selain tema dan alur, penghadiran tokoh dalam sebuah novel merupakan kunci utama yang dapat menambah kesan nyata dalam cerita.

Tokoh dan penokohan pada novel sama seperti tokoh-tokoh dalam jenis prosa lain, hanya saja tokoh dalam novel dihadirkan lebih banyak dan bervariasi. Setiap tokoh memiliki peran dan fungsi berbeda dalam cerita. Tokoh yang dihadirkan oleh pengarang merupakan tokoh rekaan atau tokohtokoh yang nyata mengalami peristiwa dalam cerita. Adapun tokoh yang dibuat merupakan cerminan atau gambaran langsung kepribadian pengarang maupun kepribadian pembaca. Oleh sebab itu, pembaca tidak sulit memahami dan merasakan jalan cerita yang sama persis dengan apa yang mereka alami. Para tokoh berperan sesuai dengan kemauan dari Sang pengarang. Tokoh utama dalam sebuah cerita biasanya berperan sebagai orang yang baik dan lemah, sehingga selalu tertindas oleh tokoh yang lebih superior. Namun, tidak sedikit tokoh utama yang digambarkan dengan kepribadian yang kuat serta berkuasa. Kepiawaian pengarang dalam menciptakan sifat atau watak dalam suatu kepribadian seorang tokoh akan membuat pembaca mudah mengikuti dan masuk ke dalam alur cerita. Itu artinya pengarang berhasil menyatukan tokohtokoh tersebut dengan penokohan yang pas dan sesuai.

Kepribadian yang tergambar dari seorang tokoh fiksi adalah hasil dari rekayasa pengarang yang direalisasikan melalui sebuah cerita. Kepribadian atau watak ini, memberikan suatu refleksi kepada Si pembaca. Kepribadiankepribadian yang terdapat pada setiap tokoh dapat dinilai baik atau buruk menurut perspektif masing-masing

Analisis Kepribadian Tokoh Kai Amak dalam Novel Galuh Hati Karya Randu Alamsyah 
penikmat sastra. Hal ini merupakan langkah awal dalam menilai kepribadian seseorang dikehidupan nyata. Banyak cara atau metode dalam mengkaji kepribadian seseorang salah satunya dengan cara psikoanalisis.

Psikoanalisis merupakan salah satu pendekatan yang digunakan dalam mengakaji atau menganalisis psikis (jiwa) manusia dalam kajian ilmu psikologi. Tokoh yang pertama kali mengenalkan teori ini adalah Sigmund Freud (bapak psikoanalis). Sigmund Freud membagi struktur psikis (jiwa) manusia menjadi tiga bagian yakni id, ego, dan super ego. Menurut Freud, id terletak di bagian alam bawah sadar manusia yang berkerja untuk pemenuhan dasar manusia seperti kebutuhan makan dan seks. Bagian kedua disebut sebagai ego, letaknya diantara alam bawah sadar dan sadar manuisa. Ego memiliki peran penting dalam membuat keputusan sesuai dengan keadaan yang realitas.Sedangkan bagian terakhir jiwa manusia disebut super ego. Super ego berperan dalam mengendalikan pemenuhaan sempurna dari $i d$, yang mengacu pada moralitas.Langkah awal yang bisa kita lakukan adalah dengan menganalisa kepribadian tokoh dalam sebuah prosa, seperti novel. Pengkajian kepribadian atau watak tokoh dalam sebuah karya sastra biasanya menggunakan pendekatan psiko-analisis. Penggunaan teori-teori psikologi, seperti psikoanalisis dalam mengkaji sebuah karya sastra disebut sebagai pengkajian psikologi sastra.

Psikologi sastra memadukan antara bidang ilmu psikologi dan ilmu sastra. Psikologi sastra tidak bisa dilakukan seenaknya. Dalam pengkajiannya seorang penulis atau peneliti wajib memahami dan mendalami kajian-kajian psikologi.
Sehingga hasil dari pengkajiannya mendapat hasil yang maksimal. "Karya sastra baik novel, drama maupun puisi di zaman modern ini sarat dengan unsurunsur psikologi sebagai manifestasi: kejiwaan, pengarang, para tokoh fiksional dalam kisahan dan pembaca" (Minderop, 2010: 53).

Salah satu novel yang terbit di awal tahun 2014 adalah novel Galuh Hati karya Randu Alamsyah. Novel Galuh Hati karya Randu Alamsyah cukup tebal yang ditulis sebanyak 293 halaman. Setelah penulis baca novel ini, penulis tidak menyangka bahwa kepribadian asli dari salah satu tokoh dalam novel tidak sesuai dengan kepribadiannya di awal cerita.Tokoh tersebut adalah tokoh Kai Amak. Pada awal cerita tokoh Kai Amak digambarkan sebagai Kakek yang baik seperti orang tua pada umumnya. Penggambaran kepribadian tokoh Kai Amak mengalami perubahan seiring perkembangan cerita, dan pada akhirnya menguak siapa Kai Amak sebenarnya yakni penghianat, pembohong, dan penipu. Kasus-kasus kepribadian seperti ini sering kita jumpai dalam kehidupan sehari-hari. Orang yang kita lihat baik dari penampilannya belum tentu baik perilakunya, begitupun sebaliknya orang yang kita lihat kurang baik dari penampilannya belum tentu buruk perilakunya.

Randu Alamsyah merupakan nama pena dari Muhammad Nur Alam Machmud, yang lahir di Manado, Sulawesi Utara. Randu Alamsyah tidak bisa dianggap remeh sebagai seorang penulis. Novel debutnya yang berjudul Jazirah Cinta yang rilis tahun 2008, dibeli hak ciptanya oleh penerbit Abadi Ilmu Sdn BHD, Malaysia.Di tahun 2012 Jazirah Cinta difilmkan oleh 
Metrowealth Pictures dengan judul 7 Petala Cinta (Penerbit Zaman, 2016). Berdasarkan pemaparan latar belakang di atas, maka penulis melakukan penelitian dengan judul Analisis Kepribadian Tokoh Kai Amak dalam Novel Galuh Hati Karya Randu Alamsyah.

Berdasarkan latar belakang yang telah diuraikan di atas, maka teridentifikasi masalah tentang kepribadian. Menurut Gardner Murphy (dalam Suryabrata, 2006: 347) kepribadian terdiri dari tiga struktur, yakni disposisi-disposisi fisiologis, kanalisasi, dan response-response bersyarat, sedangkan Menurut Sigmund Freud (dalam Minderop, 2010: 20) struktur kepribadian terdiri dari id, ego, dan super ego. Lalu, Menurut Carl Gustav Jung (dalam Suryabrata, 2006: 156) struktur kepribadian manusia tediri dari dua, yaitu: alam sadar dan alam tak sadar.

Untuk memdapatkan hasil penelitian yang terarah, maka perlu dilakukan suatu fokus dan pertanyaan penelitian. Oleh karena itu, penulis membuat fokus dan pertanyaan penelitian sebagai berikut.

Berdasarkan identifikasi masalah yang telah dikemukakan di atas, maka fokus penelitian ini adalah kepribadian menurut Sigmund Freud (dalam Minderop, 2010: 20) yang terdiri dari $i d$, ego, dan super ego pada Tokoh Kai Amak dalam Novel Galuh Hati Karya Randu Alamsyah.

Berdasarkan latar belakang dan fokus penelitian yang telah diuraikan maka pertanyaan penelitian ini yaitu:

1. Bagaimanakah kepribadian Id pada tokoh Kai Amak dalam novel Galuh Hati karya Randu Alamsyah?

2. Bagaimanakah kepribadian Super Ego pada tokoh Kai Amak dalam novel Galuh Hati karya Randu Alamsyah?

Sesuai dengan fokus dan pertanyaan penelitian, maka tujuan penelitian ini sebagai berikut.

1. Mendeskripsikan kepribadian Id tokoh Kai Amak dalam novel Galuh Hati karya Randu Alamsyah.

2. Mendeskripsikan kepribadian Super Ego pada tokoh Kai Amak dalam novel Galuh Hati karya Randu Alamsyah.

Penelitian mengenai anaisis kepribadian tokoh Kai Amak dalam Novel Galuh Hati Karya Randu Alamsyah diharapkan dapat memberikan manfaat, baik secara teoretis maupun praktis. Adapun manfaat teoretis dan praktis penelitian ini adalah sebagai berikut.

Secara teoretis, dari hasil penelitian ini dapat digunakan mahasiswa maupun peneliti pemula dalam memanfaatkan teori-teori serta konsep yang nantinya dapat dipergunakan sebagai bahan perbandingan dalam penelitianpenelitian sejenis.

Secara praktis, penelitian ini dapat bermanfaat,

1. bagi pembaca, dapat menambah pengetahuan seputar kajian psikologi sastra;

2. bagi calon guru, dapat menjadi bahan ajar sastra di sekolah;

3. bagi penulis lain, dapat menjadi bahan referensi untuk penelitian selanjutnya.

\section{METODE PENELITIAN}

Pemecahan masalah yang tepat memerlukan metode dan pendekatan yang tepat pula, oleh karena itu penulis harus mengetahui terlebih dahulu jenis, metode dan pendekatan yang akan digunakan dalam penelitian ini. 
Menurut Rahima (2017: 1) Dalam penelitian sastra terdapat beberapa sudut pandang atau pendekatan dalam menganalisisnya. Perbedaan sudut pandang inilah yang kemudian memunculkan adanya berbagai jenis penelitian sastra. Oleh karena itu, jenis penelitian tergantung sudut pandang atau pendekatan mana yang dipakai peneliti. Hal ini selanjut dipertegas oleh Gunawan, dkk, (2018: 133) yang menjelaskan bahwa jenis penelitian merupakan cara kerja suatu penelitian yang dipilih seorang peneliti dalam memahami objek penelitiannya. Jenis penelitian erat kaitannya dengan metode. Metode merupakan strategi atau cara untuk menyelesaikan masalah yang dikemukakan. Sesuai pendapat tersebut maka pendekatan yang digunakan dalam penelitian ini adalah pendekatan kualitatif. Pendekatan kualitatif digunakan untuk menjelaskan atau mendeskripsikan suatu fenomena. Hal ini sejalan dengan pendapat Yusuf (2014: 329) yang mengatakan bahwa

"Penelitian kualitatif merupakan suatu strategi inquiry yang menekankan pencarian makna, pengertian, konsep, karakteristik, gejala, simbol, maupun deskripsi suatu fenomena; fokus dan multimetode, bersifat alami dan histolik; mengutamakan kualitas, menggunakan beberapa cara, serta disajikan secara naratif."

Jenis penelitian ini adalah penelitian deskriptif. Penelitian deskriptif memecahkan masalah dengan cara menggambarkan keadaan subjek atau objek penelitian berdasarkan keadaan yang sebenarnya. Hal ini sejalan dengan pendapat Siswantoro (2010: 56) bahwa

"Metode deskriptif dapat diartikan sebagai prosedur pemecahan masalah yang diselidiki dengan menggambarkan atau melukiskan keadaan subjek atau objek penelitian (novel, drama, cerita pendek, puisi) pada saat sekarang berdasarkan fakta-fakta yang tampak atau sebagaimana adanya."

Dapat disimpulkan bahwa penelitian ini menggunakan pendekatan dan jenis penelitian deskriptif kualitatif. Data merupakan bagian vital dari sebuah penelitian. "Data merupakan perwujudan dari informasi dengan sengaja digali untuk dikumpulkan guna mendeskripsikan suatu peristiwa atau kegiatan yang lainnya, demikian pula halnya untuk menguji hipotesa yang telah dirumuskan (Subagyo, 2006: 38). Data yang digunakan untuk memecahkan suatu masalah dalam penelitian harus mengandung informasi.

Data merupakan sumber informasi yang digunakan untuk mendapatkan hasil penelitian. "Data adalah sumber informasi yang akan diseleksi sebagai bahan analisis" (Siswantoro, 2010: 70). Maka dari itu, data juga perlu diseleksi sesuai dengan kebutuhan dan kepentingan dari penelitian.

Sumber data dari penelitian ini adalah kata-kata, kalimat-kalimat, dan ungkapan-ungkapan yang menggambara-kan kepribadian id, ego, dan super ego pada tokoh Kai Amak dalam novel Galuh Hati karya Randu Alamsyah. Selain itu, penulis juga menggunakan sumber pendukung dari buku-buku literatur yang berkaitan dengan penelitian.

Adapun teknik pengumpulan data yang digunakan penulis dalam penelitian ini adalah dokumen.

1. Teknik Dokumen

Dokumen merupakan catatan atau karya seseorang tentang sesuatu

Analisis Kepribadian Tokoh Kai Amak dalam Novel Galuh Hati Karya Randu Alamsyah 
yang sudah berlalu. Dokumen tentang orang atau kelompok orang, peristiwa, atau kejadian dalam situasi sosial yang sesuia dan terkait dengan fokus penelitian adalah sumber informasi yang sangat berguna dalam penelitian kualitatif. Dokumen itu dapat berbentuk teks tertulis, artefacts, gambar, maupun foto (Yusuf, 2014: 391). Dalam penelitian ini penulis melakukan teknik pengumpulan data struktural yang diperkenalkan oleh Levi-Strauss (dalam Rafiek, 2010: 76). Adapun langkahlangkah dalam teknik pengumpulan datanya sebagai berikut.

1. Membaca dengan teliti dan saksama novel Galuh Hati karya Randu Alamsyah secara berulang-ulang.

2. Membaca dan memahami ungkapanungkapan yang terdapat dalam novel Galuh Hati karya Randu Alamsyah.

3. Penulis mengulang kembali membaca buku sumber lain tentang $i d$, ego, dan super ego pada aspek kepribadian.

4. Penulis menandai pada bagian katakata, kalimat, atau paragraf yang berhubungan dengan kepribadian $i d$, ego, dan super ego pada tokoh Kai Amak dalam novel Galuh Hati karya Randu Alamsyah.

5. Penulis mencatat aspek-aspek yang berkaitan dengan kepribadian $i d$, ego, dan super ego pada tokoh Kai Amak dalam novel Galuh Hati karya Randu Alamsyah.

6. Kemudian penulis mengumpulkan data yang berhubungan dengan kepribadian id, ego, dan super ego pada tokoh Kai Amak dalam novel Galuh Hati karya Randu Alamsyah.

Setelah data terkumpul, selanjutnya penulis menganalisis data yang telah diperoleh. "Analisis data adalah proses mengorganisasikan dan mengurutkan data ke dalam pola, kategori, dan satuan uraian dasar sehingga dapat ditemukan tema dan dapat dirumuskan hipotesis kerja seperti yang disarankan oleh data" (Ismawati, 2012: 15-16). Jadi, teknik analisi data merupakan kegiatan penjabaran data yang telah terkumpul. Teknik analisis data yang digunakan untuk menganalisis data kepribadian $i d$, ego, dan super ego dari tokoh Kai Amak dalam novel Galuh Hati karya Randu Alamsyah. Pada penelitian ini, penulis menggunakan teknik analisis data oleh Siswantoro (2010: 81). Kegiatan analisis data dilakukan dengan langkah-langkah sebagai berikut.

1. Data yang didapat,dikelompokan ke dalamtabel tabulasi data.

2. Setelah ditabulasi, langkah selanjutnya yaitu menginterpretasikan data yang sudah ditabulasikan dengan kerangka teori.

3. Data yang telah diinterpretasikan kemudian data tersebut dianalisis sesuai dengan teori yang berkaitan masalah penelitian.

4. Keabsahan data, mengecek data temuan dengan temuan lain sehingga tidak adanya kekontrasan atau kesesuaian antara satu dengan yang lainnya.

5. Mendeskripsikan data berdasarkan analisis kepribadian id, ego, dan super ego tokoh Kai Amak dalam novel Galuh Hati karya Randu Alamsyah.

6. Merumuskan kesimpulan.

\section{HASIL DAN PEMBAHASAN}

Hasil penelitian yang ditemukan adalah pada tokoh Kai Amak dalam novel Galuh Hati karya Randu Alamsyah banyak terdapat ungkapan yang menggambarkan kepribadian id, ego dan super ego. Jumlah ungkapan dari ketiga aspek kepribadian tersebut sebanyak 45 ungkapan.

Analisis Kepribadian Tokoh Kai Amak dalam Novel Galuh Hati Karya Randu Alamsyah 


\section{Kepribadian Id}

Id merupakan salah satu bagian dari psikis (jiwa) yang terletak alam bawah sadar manusia.id memberi energi pada naluri-naluri atau dorongan kebutuhan dasar (primitif) manusia. Naluri-naluri tersebut diantaranya: makan, seks, dan penolakan atas rasa sakit atau tidak nyaman. Ungkapan yang mengambarkan kepribadian id dari tokoh Kai Amak ditemukan sebanyak 16 ungkapan.

\section{Kepribadian Super Ego}

Sama halnya dengan id, Super ego bagian dari psikis (jiwa) yang terletak pada alam bawah sadar manusia. Super egosama halnya dengan "hati nurani" yang mampu mengenali nilai baik dan buruk. Super ego dibentuk dari larangan dan perintah yang datang dari luar seperti norma, ajaran maupun orang tua. Hal ini yang menumbuhkan emosi-emosi seperti rasa malu, bersalah, dan menyesal. Ungkapan yang mengambarkan kepribadian super egodari tokoh Kai Amak ditemukan sebanyak 9 ungkapan.

Penelitian ini membahas tentang analisis aspek kepribadian tokoh Kai Amak dalam Novel Galuh hati karya Randu Alamsyah. Pembahasan analisis ini mengenai 3 aspek kepribadian, yang terdiri dari id, ego, dan super ego. Aspek kepribadian pertama adalah id terdiri dari naluri makan dan minum, seks serta menolak rasa sakit atau tidak nyaman. Aspek kepribadian kedua adalah ego terdiri dari penalaran, penyelesaian masalah, serta pengambilan keputusan, dan aspek kepribadian ketiga adalah super ego terdiri dari rasa malu, bersalah serta menyesal. Ketiga aspek ini akan dideskripsikan sebagai berikut.

\section{Kepribadian Id}

Id adalah naluri yang mendorong manusia untuk memenuhi kebutuhan dasar atau primitif seperti makan, seks (kebutuhan biologis), penolakan atas rasa sakit atau tidak nyaman (Freud dalam Minderop, 2010: 21). Nalurinaluri ini harus segera dilaksanakan untuk mencapai rasa senang dan puas. $I d$ terletak di alam bawah sadar manusia.

a. Naluri Makan dan Minum

Makan adalah kebutuhan manusia yang paling dasar untuk bertahan hidup. Keinginan kita untuk makan adalah produk dari sebuah sistem dalam otak kita. Sistem itu terdiri dari 6 bagian, yaitu stimulus, urge, desire, action, evidence, dan reward. Stimulus merupakan rangsangan yang dapat berasal dari otak atau penglihatan kita tentang makanan. Stimulus diolah menjadi sebuah pesan (lapar) yang disebut urge. Lalu urge diubah menjadi sesuatu yang lebih nyata yakni desire (dorongan makan). Kemudian dorongan ini memunculkan action (makan). Saat makan sensor dalam mulut mengirim bukti ke otak bahwa keinginan sedang dijalankan (evidence). Dan tibalah pada fase reward, di mana otak mendapat pesan bahwa dorongan makan telah terpenuhi (Abdurakhman, 2018 :128). Ungkapan yang menggambarkan naluri makan dan minum terdapat pada ungkapan-umgkapan berikut ini:

Sebagai istrinya, aku mulai mengenali kebiasaan-kebiasaannya: dia biasa terbangun di pagi hari tanpa suara, membuang dahak di pintu atau lewat jendela, duduk dan meminum kopi yang kusediakan untuknya, lalu merokok satu atau dua batang. (GH, RA: 2014 :238)

Dalam ungkapan di atas terdapat naluri minum dari aspek kepribadian $i d$ tokoh Kai Amak. Di pagi hari setelah

Analisis Kepribadian Tokoh Kai Amak dalam Novel Galuh Hati Karya Randu Alamsyah 
bangun tidur Kai Amak memiliki kebisaan minum kopi. Ia meminum secangkir kopi untuk memenuhi kebutuhan minum atas rasa hausnya. Perilaku Kai Amak yang minum di saat sedang haus selalu terjadi dalam kehidupan nyata. Untuk bertahan hidup manusia butuh minum.

Tangannya menempel di piring masih berusaha menyuap nasi dan kunyahannya berhenti dengan pipi gembung. Dia berdecak dan meminum airnya. (GH, 2014: 241)

Dalam ungkapan tersebut terdapat naluri makan dan minum dari aspek id tokoh Kai Amak.Kai Amak memakan makanan dan minuman yang ada di hadapannya. Hal iniialakukan untuk memenuhi kebutuhan makan dan minum atas rasa lapar dan hausnya. Perilaku Kai Amak yang makan dan minum di saat sedang lapar dan haus sering terjadi dalam kehidupan nyata. Untuk bertahan hidup manusia butuh makan dan minum.

Ia hanya minta dibayari nasi sop atau katupat yang akan kami singgahi setiap kali pulang dari sana. (GH, RA : 2014: 48)

Dalam ungkapan tersebut terdapat naluri makan dari aspek kepribadian id tokoh Kai Amak. Kai Amak bersama temannya selalu mampir di sebuah warung yang menyediakan nasi sop dan ketupat kesukaanya. Kai Amak sering memakan nasi sop atau ketupat sebagai pemenuhan kebutuhan makan atas rasa laparnya. Perilaku Kai Amak yang makan di saat sedang lapar selalu terjadi dalam kehidupan nyata. Untuk bertahan hidup manusia butuh makan. Jika naluri atau dorongan ini sulit untuk dipenuhi bisa mengakibatkan orang melakukan hal-hal yang menyimpang seperti tindakan kriminal diantaranya mencuri, merampok, dan lain-lain untuk memenuhi dorongan tersebut. Lain halnya jika naluri atau dorongan ini dapat terpenuhi dengan mudah maka orang akan merasa senang dan nyaman. Ungkapan-ungkapan di atas memiliki relevansi dengan teori yang diungkapkan oleh Abdurakhman (2018: 128) dan Freud (dalam Minderop, 2010: 20).

b. Naluri seks

Seks adalah bagian yang tak bisa dipisahkan dari kehidupan manusia. Seks merupakan cara manusia untuk memberikan perhatian kepada pasangannya serta meneruskan keturunan. Bisa dipastikan hampir semua pasangan suami istri, tentunya sangat mendambakan keturunan Madani (2003: 149). Ungkapan yang menggambarkan naluri seks (kebutuhan biologis) terdapat pada ungkapanungkapan berikut ini.

Kami melangsukan pernikahan rahasia di tahun 1960, saat semua orang sedang disibukan oleh kesulitan ekonomi. (GH, RA: 2014: 238)

Dalam ungkapan di atas terdapat naluri seks dari aspek kepribadian id tokoh Kai Amak. Untuk menyalurkan hasrat biologis atau seks yang sehat dan sah, Kai Amak melakuakan pernikahan. Pernikahan dilakukan agar mempermudah pemenuhan hasrat biologis atau seks dari Kai Amak. Perilaku Kai Amak ini sering terjadi dalam kehidupan nyata. Laki-laki dan wanita yang telah dewasa akan melakukan pernikahan untuk menyalurkan hasrat seksualitas yang sehat.

Seiring dengan itu, kami kemudian mendapatkan seorang anak lelaki dua tahun berikutnya. Segera setelah kelahiran Abdul kami merasakan kehidupan membaik. (GH, 2014: 239)

Analisis Kepribadian Tokoh Kai Amak dalam Novel Galuh Hati Karya Randu Alamsyah 
Dalam ungkapan tersebut terdapat naluri seks dari aspek id tokoh Kai Amak.Setelah menjalani pernikahan selama dua tahun. Kai Amak dan istrinya dikaruniai seorang anak lakilaki.Anak tersebut merupakan hasil dari pemenuhan aktivitas seksual yang dilakukan oleh Kai Amak terhadap istrinya.Perilaku Kai Amak ini sering terjadi dalam kehidupan nyata. Untuk mendapatkan keturunan maka manusia akan melakuka hubungan seks. Jika naluri atau dorongan seks tersalurkan dengan baik maka akan menyebabkan seseorang mudah marah dan tidak bahagia dalam kehidupannya. lain halnya jika naluri atau dorongan ini tersalurkan dengan baik maka orang tersebut akan merasa senang dan bahagia. Ungkapan-ungkapan di atas memiliki relevansi dengan teori yang diungkapkan oleh Madani(2003:149) dan Freud (dalam Minderop, 2010: 22).

c. Naluri Menolak Rasa Sakit Atau Tidak Nyaman

Rasa sakit adalah rasa yang tidak enak bagi penderita. Rasa sakit dapat menimpa siapa saja, ridak memandang kaya-miskin, besar-kecil, tua-muda, bodoh atau pintar.Penderitaan yang berupa rasa sakit dann siksaan merupakan satu rangkaian peristiwa yang tidak dapat dipisah-pisahkan. Dalam pengalaman hidup sehari-hari manusia dikenal adanya tiga macam rasa sakit, yaitu sakit hati, syaraf atau jiwa, dan sakit fisik. Jadi, dorongan menolak rasa sakit atau tidak nyaman merupakan dorongan yang dilakukan dari dalam diri seseorang atas rasa sakit atau tidak nyaman dari sakit hati, jiwa maupun fisik (Sujarwa, 1999: 66). Ungkapan yang menggambarkan naluri menolak rasa sakit atau tidak nyaman terdapat pada ungkapan-ungkapan berikut ini:
Karena sudah tak kuasa menahannya, aku menceritakan kisahku kepada Sari dengan harapan dadaku akan sedikit lebih ringan. Aku mengatakan kepadanya bahwa aku mencintai Sarah. (GH, RA : 2014: 58)

Dalam ungkapan di atas terdapat penolakan atas rasa saki (hati) dari aspek kepribadian id tokoh Kai Amak. Kai Amak mencurahkan segala perasaan yang selama ini membuat sakit hatinya kepada sepupunya, Sari. Kai Amak mengatakan kepada Sari bahwa dia tidak suka dan tidak nyaman terhadap hubungan yang dijanani oleh temannya, Antas dan sarah. Hal ini ia lakukan untuk membuat rasa sakit hati yang ia pendam selama ini sedikit berkurang. Perilaku Kai Amak ini sering terjadi dalam kehidupan nyata. Saat seseorang sedang merasa sakit hati dia perlu meluapkan perasaan tersebut kepada orang lain, dengan harapan hal ini dapat mengurangi beban masalah yang tengah dihadapi. Akibat dari sakit hati seseorang dapat melakukan hal-hal negatif. Seperti melakukan balas dendam atau menyakiti orang yang menjadi penyebab dari rasa sakit hati tersebut. Sakit hati tidak hanya dapat merugikan orang lain bahkan dapat merugikan diri sendiri. Maka dari itu, jika kita sedang merasa sakit hati terhadap sesuatu hal hendaknya kita dapat memaafkan sumber sakit hati tersebut. Hal ini akan membuat jiwa kita menjadi lebih sehat dan tenang.

Aku memberi jalan dan mendengarkan orang-orang berbicara tentang Kai Amak tidak dapat melanjutkan pendulangannya di hari pertama. Dia kelelahan dalam beberapa kali ayakan. (GH, 2014: 34)

Dalam ungkapan tersebut terdapat penolakan atas rasa sakit (fisik) dari aspek id tokoh Kai Amak.Kai Amak 
mengalami kelelahan saat mendulang. Kai Amak langsung menghentikan kegiatan mendulangnya. Hal ini ia lakukan untuk menghilangkan rasa lelah. Perilaku Kai Amak ini sering terjadi dalam kehidupan nyata. Saat seseorang merasa lelah pada tubuhnya mereka akan menghentikan aktivitas yang sedang dilakukan agar rasa lelah tersebut berkurang atau menghilang. Jika rasa lelah ini tidak dihilangkan dengan segera, maka seseorang akan merasakan sakit fisik yang dapat mengganggu aktivitas sehari-harinya. Rasa lelah yang telah hilang akan membuat tubuh seseorang menjadi lebih tenang dan nyaman.

Jadi, saat kau mencoba mencari tahu tentang Antas dan Galuh Hati dia mencurigai kau telah mendapatkan setengah dari bagian cerita yang dikisahkannya kepadamu. Tidak ada yang mengetahui tentang hal itu. Jadi, saat itu Kai Amak yang panik akhirnya melakukan sesuatu untuk menghambatmu. (GH, RA : 2014: 260)

Dalam ungkapan tersebut terdapat rasa tidak nyaman dari aspek kepribadian id tokoh Kai Amak. Kai Amak memerintahkan anak buahnya untuk menghabisi Abul. Kai Amak takut rahasianya akan diketahui oleh Abul dan seluruh warga Cempaka. Hal ini ia lakukan untuk menghilangkan rasa tidak nyaman yang disebabkan oleh Abul. Perilaku ini sering terjadi dalam kehidupan nyata. Saat seseorang sedang merasa tidak nyaman dan terancam oleh orang lain mereka akan melakukan sesuatu untuk dapat mempertahankan diri dari ancaman tersebut. Jika rasa tidak nyaman ini diabaikan maka seseorang akan merasakan keresahan dalam dirinya sehingga mengganggu aktivitas sehari-hari. Lain halnya jika rasa tidak nyamn telah hilang maka seseorang dapat menjalani kehidupan dengan tenang dan nyaman. Ungkapanungkapan di atas memiliki relevansi dengan teori yang diungkapkan oleh Sujarwa (1999: 66) dan Freud (dalam Minderop, 2010: 22).

\section{Kepribadian Super Ego}

Super ego merupakan struktur ketiga dari kepribadian manusia. Super egosama halnya dengan "hati nurani" yang mampu mengenali nilai baik dan buruk. Super ego dibentuk dari larangan dan perintah yang datang dari luar seperti norma, ajaran maupun orang tua. Hal ini yang menumbuhkan emosiemosi seperti rasa malu, bersalah, dan menyesal (Firdaus dalam Wahyuningtyas \& Santosa, 2011: 13). Super ego terletak di alam bawah sadar.

\section{a. Rasa Malu}

Setiap orang entah apapun status, jabatan atau pekerjaannya, pasti mempunyai rasa malu. Orang-orang yang menderita rasa malu jiwanya seperti terbelah. Dalam diri mereka ada dorongan untuk melakukan hal-hal yang baik dan perlu.Tetapi sekaligus mereka merasakan ada kekuatan yang menahannya. Rasa malu membuat orang-orang tidak dapat bertingkah dengan wajar, berbicara dengan baik dan berprestasi dengan normal (Mangunhardjana, 2012: 18). Ungkapan yang menggambarkan rasa malu terdapat pada ungkapan-ungkapan berikut ini:

Aku mencegat perempuan itu saat dia kembali dari kebun bunga. Itu pertama kalinya aku berdiri di depan wanita cantik dan hatiku berdesir. Sesaat aku tidak tahu apa yang akan kukatakan. (GH, RA: 2014: 53)

Dalam ungkapan di atas terdapat rasa malu dari aspek kepribadian super ego tokoh Kai Amak. Kai Amak mencegat Sarah yang kembali dari

Analisis Kepribadian Tokoh Kai Amak dalam Novel Galuh Hati Karya Randu Alamsyah 
kebun bunga. Saat berhadapan dengan Sarah hatinya berdesir dan bingung mau mengatakan apa. Perilaku ini sering terjadi dalam kehidupan nyata. Saat seseorang sedang merasa malu, maka, akan mengalami gejolak yang tidak wajar pada dirinya. Rasa malu dapat mengontrol perilaku seseorang sehingga tidak melanggar norma-norma yang ada. Jika seseorang tidak memiliki rasa malu maka orang tersebut akan melakukan hal-hal yang dapat bertentangan dengan norma maupun moral.

Sarah menanyakan kabarku sementara aku sibuk menata debaran jantungku.Ku katakan padanya aku baik-baik saja.Saat itu dia terusmenerus menatapku. (GH, RA : 2014: 58)

Dalam ungkapan tersebut terdapat rasa malu dari aspek super ego tokoh Kai Amak.Sarah menyapa dan menanyakan kabar Kai Amak.Jantungnya selalu berdebar setiap kali bertemu dengan Sarah.Perilaku ini sering terjadi dalam kehidupan nyata. Saat seseorang sedang merasa malu, maka, akan mengalami gejolak yang tidak wajar pada dirinya. Rasa malu dapat mengontrol perilaku seseorang sehingga tidak melanggar norma-norma yang ada. Jika seseorang tidak memiliki rasa malu maka orang tersebut akan melakukan hal-hal yang bertentangan dengan norma maupun moral. Ungkapan-ungkapan di atas memiliki relevansi dengan teori yang diungkapkan oleh Mangunhardjana (2012: 18), Firdaus (dalam Wahyuningtyas \& Santosa, 2011: 12-13) dan Freud (dalam Minderop, 2010: 22).

\section{b. Rasa Bersalah}

Rasa bersalah merupakan perasaan yang umum dan mudah di atasi dengan cara mengakuinya dan tidak mengulangi masalah itu (Wright, 2013: 199). Ungkapan yang menggambarkan rasa bersalah terdapat pada ungkapanungkapan berikutini:

Aku memberikan surat yang sepanjang malam ku karang sendiri. Konsekuensi dari hal itu sempat terpikir olehku, tapi percayalah jika kau melihat wajah Antas, berteman dengannya, dan merasakan limpahan kebaikannya, kau bahkan rela menyerahkan sepotong jarimu hanya untuk menyenangkan hatinya. (GH, 2014: 53)

Dalam ungkapan di atas terdapat rasa bersalah dari aspek super ego tokoh Kai Amak. Kai Amak merekayasa surat cinta antara Antas dan Sarah. Kai Amak melakukan ini karena dia ingin membantu sahabatnya, Antas. Kai Amak tahu bahwa perbuatannya salah, dia siap menanggung konsekuensi atasapa yang telah ia lakukan. Perilaku ini sering terjadi dalam kehidupan nyata.Seseorang dapat melakukan sebuah kesalahan baik disengaja maupun tidak disengaja. Rasa bersalah dapat muncul akibat perbuatan atau perilaku kita yang keliru maupun melanggar peraturan.Agar rasa bersalah ini tidak muncul maka sebaiknya kita selalu berbuat dan bertindak dengan benar dan tidak melanggar peraturan yang ada.Kajian ini memiliki relevansi dengan teori yang diungkapkan oleh Wright (2013: 199) danFirdaus (dalam Wahyuningtyas \& Santosa, 2011: 12-13) dan Freud (dalam Minderop, 2010: 22).
c. Rasa Menyesal
Menyesal merupakan suatu perasaan, emosi, dan kegelisahan yang terkait dengan urusan hati. Ia merupakan ungkapan dari sikap meratapi berbagai dosa yang telah dilakukan seseorang terhadap hak tuhannya, hak sesama makhluk, dan hak dirinya sendiri (Al- qardhawi, 2008: 71). Ungkapan yang 
menggambarkan rasa menyesal terdapat pada ungkapan-ungkapan berikut ini:

Sejenak Kai Amak terpaku dan menyadari apa yang dilakukannya. Air mata bercampur lelehan hujan membasahi wajahnya. "Antas, Antas apa yang telah kulakukan. $(G H, 2014$ : 251)

Dalam ungkapan di atas terdapat rasa menyesal dari aspek super ego tokoh Kai Amak.Kai Amak membunuh temanya sendiri demi cinta. Setelah melihat Antas telah terbujur kaku di hadapannya.Kai Amakpun menangis. Hal ini dikarenakan ia menyesal telah membunuh teman yang telah dianggap sebagai saudaranya sendiri hanya karena seorang wanita. Perilaku ini sering terjadi dalam kehidupan nyata.

Dia tenggelam dalam depresi dan selama itu tidak melakukan apapun kecuali mengurung diri di dalam kamarnya. Cahaya matahari melintas di jendela dan sesaat lagi kegelapan datang mencabik-cabik hatinya, menenggelamkannya dalam penyesalan. (GH, RA: 2014: 253)

Dalam ungkapan tersebut terdapat rasa menyesal dari aspek kepribadian super ego tokoh Kai Amak. Kai Amak sering mengalami depresi lalu mengurung diri di dalam kamar. Kala malam tiba, Kai Amak selalu dibayangbayangi oleh dosa-dosanya di masa lalu. Semua itu mencabik-cabik batinnya. Hal ini dikarenakan ia merasa sangat bersalah dan menyesal atas apa yang telah ia lakukan di masa lalu. Perilaku ini sering terjadi dalam kehidupan nyata. Setiap aku melihat Antas pergi ke rumpun-rumpun bunga aku berusaha mengabaikan perasaan itu, menyepelekannya, mengingat kebodohan diri sendiri, dan menyadari atas ketidakpantasan diriku. Namun, hal itu justru menambah siksaan batin bagiku. (GH, RA: 2014: 57)

Dalam ungkapan tersebut terdapat rasa menyesal dari aspek kepribadian super ego tokoh Kai Amak. Kai Amak selalu menganggap dirinya sebagai orang yang bodoh, ketika melihat Antas menemui sarah. Semakin ia mengabaikan perasaan tersebut semakin membuat batinnya tersiksa. Hal ini dikarenakan ia menyesal telah menjodohkan Antas dengan Sarah, gadis yang ia cintai. Perilaku ini sering terjadi dalam kehidupan nyata. Seseorang akan meresa menyesal setelah melakukan suatu perbuatan yang salah di masa lalu yang dapat merugikan diri sendiri di masa sekarang. Rasa menyesal yang berlebihan akan mengakibatkan seseorang bertindak di luar akal sehat, seperti ingin mengahiri hidup, menyakiti diri sendiri dan sebagainya. Maka dari itu, sebaiknya rasa menyesal harus kita sikapi dengan wajar dan berusaha agar tidak melakukan atau mengulangi kesalahan yang sama. Ungkapanungkapan di atas memiliki relevansi dengan teori yang diungkapkan oleh $\mathrm{Al}$ qardhawi (2008:71), Firdaus (dalam Wahyuningtyas \& Santosa, 2011: 12-13) dan Freud (dalam Minderop, 2010: 22).

\section{SIMPULAN}

Berdasarkan hasil penelitian dan pembahasan yang telah dijabarkan, dapat diambil kesimpulan bahwa terdapat 45 ungkapan yang menggambarkan kepribadian id, ego, dan super ego dalam novel Galuh Hati karya Randu Alamsyah. Dapat disimpulkan sebagai berikut.

1. Aspek kepribadin id dalam novel Galuh Hati karya Randu Alamsyah tergambar dari ungkapan-ungkapan tokoh Kai Amak dalam novel tersebut yang mama selalu berusaha memenuhi dorongan atau naluri-

Analisis Kepribadian Tokoh Kai Amak dalam Novel Galuh Hati Karya Randu Alamsyah 
naluri primitifnya yakni makan dan minum, seks, serta menolak rasa sakit atau tidak nyaman. Kai Amak selalu mengutamakan pemenuhan naluri makan dan minum dari id-nya. Hal ini tentu dilakukannya untuk bertahan hidup. Naluri makan dan minum ini dipenuhi masih dalam tahap yang wajar dan tidak berlebihan. Ungkapan yang berkaitan dengan aspek kepribadian id dalam novel Galuh Hati karya Randu Alamsyah terdapat 16 ungkapan. Terdiri dari 8 ungkapan naluri makan dan minum, 2 ungkapan naluri seks, dan 6 ungkapan naluri menolak rasa sakit atau tidak nyaman.

2. Aspek kepribadinsuper ego dalam novel Galuh Hati karya Randu Alamsyah tergambar dari ungkapanungkapan tokoh Kai Amak dalam novel tersebut yang merasa malu, bersalah dan menyesal atas tindakantindakan yang telah dilakukan akibat dari melanggar nilai moral dan norma yang berlaku. Kai Amak merasa sangat menyesal atas perbuatan dosadosa yang telah ia lakukan di masa lalu. Dia menyesal karena telah membunuh temannya serta membohongi istrinya. Penyesalan dari super ego-nya ini, menyebabkan Kai Amak mengalami depresi. Ungkapan yang berkaitan dengan aspek kepribadian super ego dalam novel Galuh Hati karya Randu Alamsyah terdapat 9 ungkapan. Terdiri dari 2 ungkapan rasa malu, 1 ungkapan rasa bersalah, dan 6 ungkapan rasa menyesal.

\section{SARAN}

Berdasarkan kesimpulan yang telah penulis sampaikan, maka Kerinci Provinsi. Aksara: Jurnal Ilmiah Pendidikan Bahasa dan Sastra Indonesia, 2(1), 130-141. diharapkan pada masa yang akan datang kepada peneliti lain agar dapat melakukan penelitian yang lebih mendalam lagi dalam meneliti kepribadian ini. Dari ketiga aspek tersebut penulis mengajukan beberapa saran sebagai berikut.

1. Diharapkan dengan penelitian ini, dapat menambah kecintaan terhadap hasil karya sastra dan dapat mempelajari serta lebih memahami kajian ilmu psikologi yang berkaitan dengan kepribadian.

2. Dengan meneliti novel ini, diharapkan para pembaca dapat cerdas dalam memilih bacaan, sehingga ada manfaat yang dapat diambil dari bacaan tersebut.

3. Dari penelitian yang telah dilakukan, diharakan dapat dijadikan sebagai acuan bagi peneliti lain yang akan mengkaji objek yang sama dengan pendekatan yang berbeda.

\section{DAFTAR PUSTAKA}

Abdurakhman, Hasanudin. (2018). Melawan Miskin Pikiran 2; Belajar Sekolah Sukses Kaya. Bandung: Nuansa Cendekia.

Alamsyah, Randu. (2014). Galuh Hati. Jakarta: Moka Media.

Al-Qardawi, Yusuf. (2008). Kitab Petunjuk Taubat: Kembali Ke Cahaya Allah. Bandung: Mizania.

Gunawan, E., Rahima, A., \& Supriyati, S. (2018). Analisis Tema ungkapan Tradisional Bapeno di Desa Hiang Kecamatan Sitinjau Laut Kabupaten

Iswawati, Esti. (2012). Metode Penelitian Pendidikan Bahasa \& Sastra. Yogyakarta: Ombak.

Analisis Kepribadian Tokoh Kai Amak dalam Novel Galuh Hati Karya Randu Alamsyah 
Madani, Yusuf. (2003). Pendidikan Seks Untuk Anak Dalam Islam.

Jakarta: Pustaka Zahra.

Mangunhardjana, A.M. (2012).

Mengatasi Hambatan-Hambatan

Kepribadian. Yogyakarta:

Minderop, Albertine. (2010). Psikologi Sastra: Karya Sastra, Metode, Teori, dan Contoh Kasus. Jakarta: Pustaka Obor.

Rafiek, M. (2010). Teori Sastra. Bandung: Refika Aditama.

Rahima, A. (2017). Literature Reception (a Conceptual Overview). Jurnal Ilmiah Dikdaya, 6(1), 1-16.

Siswantoro. (2010). Metode Penelitian Sastra; Analisis Struktur Puisi.Yogyakarta: Pustaka Belajar.

Subagyo, P. Joko. (2006). Metode Penelitian Dalam Teori Dan Praktek. Jakarta: Rineka Cipta.

Sujarwa. (1999). Manusia Dan

Fenomena Budaya Menuju Perspektif Mmoralitas Agama. Yogyakarta: Pustaka Belajar.

Suryabrata, Sumadi. (2006). Psikolog Kepribadian. Jakarta: Grafindo Persada.

Wahyuningtyas, Sri \& Wijaya Heru Santosa. (2011). Sastra Teori dan Implementasi. Surakarta: Yuma Pustaka.

Wright, Susan. (2003). Be Your Own Therapist. Yogyakarta: Kanisius.

Yusuf, A. Muri. (2014). Metode Penelitian; Kuantitatif, Kualitatif \& Penelitian Gabungan. Jakarta: Kencana. 